\title{
Design of coal mine drainage system
}

\author{
Waterman Sulistyana Bargawa, ${ }^{1, *}$, Agus Panca Adi Sucahyo $^{1}$, and Hesti Farra Andiani ${ }^{2}$ \\ ${ }^{1}$ Master of Mining Engineering, UPN Veteran Yogyakarta, JL. SWK 104 Yogyakarta, 55281, Indonesia \\ ${ }^{2}$ Mining Engineering Department, UPN Veteran Yogyakarta, JL. SWK 104 Yogyakarta, 55281, Indonesia
}

\begin{abstract}
Research from coal fields show that increased production from coal mines resulted in a wider pit. Changes in the water catchment area resulted in changes in the calculation of mine water volume. Excessive mine water volume affects mining activities. Large amounts of water in the pit causes disruption in excavation and loading and hauling activities. Therefore, the design of mine drainage systems is required. The purpose of the study is to analyse statistically the parameters of the mine drainage system, and to design the mine drainage system; including open drain, sump, and settling pond. The research tools used include the calculation of runoff water discharge that requires statistical analysis for rainfall data processing and the determination of catchment area (CA). The open channel dimension and settling pond design is based on the sump volume calculation. The research area has high rainfall classification, solid percent $2.66 \%$ with settling rate $0.0027 \mathrm{~m} / \mathrm{s}$; the time required for the particle to settle is 30.38 minutes. The percentage of theoretically suctioned particle is $83 \%$, and the settling pond maintenance time that has 4 compartments is $15,16,19$, and 23 days.
\end{abstract}

\section{Introduction}

The mine water problem is a major challenge for the development of the coal mining industry in terms of increasing the coal production. Not only is water a necessary resource, but also is has the potential to disrupt coal mining activities. Several studies have been developed on mine water related to the potential problem of disruption to coal mining activities [1-3]. Implementation of surface mining system and open pit method in coal mine cause the interaction of sulphide mineral, water and air. Mine water in large quantities is a major cause of environmental pollution [4,5]. Mine water excess requires appropriate handling. The coal mining business requires good and proper management in order to mitigate this problem.

The phenomenon of heavy rainfall cannot be prevented therefore causing water to accumulate and inundate the mine pit bottom requiring large-capacity pumps to remove the water [6]. The excess mine water creates an accumulation of mud from being saturated with additional rainwater. Water accumulation, mud layers, mud sediments and wet mining areas are a problem that complicates activity in coal mining leading to the following: (a) large amounts of mine water inhibits production targets especially in wet months (during the rainy season) when all aquifers are filled with water [7], (b) the drainage systems, designed to keep the mine pit bottom in dry conditions is overburdened [8], therefore production targets cannot be achieved, (c) wet areas and mud sediments are hazardous conditions related to safety and health aspects of coal mines [9], (d) handling mine water containing sludge and acidic sediments is required before the water flows into the river [10-12].

In terms of design and implement of effective mine drainage systems, research is needed to determine the stages of mine drainage design to ensure the coal mining environment is protected from pollution problems, and long-term sedimentation. This study aims to; (a) perform statistical analyses of parameters in the mine drainage system to be used in the mining area; (b) design a mine drainage system covering open channels, mine water pumping on wells and treatment of settling ponds.

\section{Methods and material}

\subsection{Parameter of mine drainage system}

Weather uncertainty related to rainfall frequency analysis is evaluated by applying it to the Gumbel distribution model. This model shows the variability [13] of parameter uncertainty. Gumbel distribution is considered most appropriate because it is equipped with maximum daily rainfall for time period variations, and repeated rainy periods $[14,15]$. The analysis indicates that the rainfall of various time periods and rainfall periods represents a certain percentage of the average annual rainfall.

$$
X r=\bar{X}+\frac{d x}{2 n}\left(Y_{r}-Y_{n}\right)
$$

where: $X r=$ rainfall plan with certain repetitive period $(\mathrm{mm} /$ day $), \bar{X}=$ daily average rainfall $(\mathrm{mm}), \delta x=$ standard deviation of rainfall value from data, $\delta n=$ standard

\footnotetext{
* Corresponding author: waterman.sb@upnyk.ac.id
} 
deviation from variate reduction depending on the amount of data), $Y r=$ the variate reduction value of the expected variable, $Y n=$ the mean value of the varied reduction, depending on the number of data.

Knowledge of maximum daily rainfall and rainfall periods is an important topic in engineering, especially mining. Flood hazard can be associated with one or a combination of rainfall, geology, topography [16]. Extreme rainfall or heavy rain in a short time can lead to flash floods. Mononobe formula is used to estimate of various durations [17] such as rainfall of 1 hour, 2 hours, 3 hours, 5 hours, 8 hours, of the maximum annual value. This formula is used to estimate short duration rainfall from daily rainfall data. This formula provides the best estimates of short duration rainfall.

$$
I=\frac{R_{24}}{24}\left(\frac{24}{t}\right)^{2 / 3}
$$

where $I=$ rainfall intensity $(\mathrm{mm} / \mathrm{h}), t=$ rainfall time or constant time (hr), $R_{24}=$ maximum rainfall (mm).

The entire catchment area is divided into sub unit of catchment area. Each sub unit of the catchment area is assumed to be uniform. Each sub-watershed consists of a mixture of flowing water flows to the same destination point, which corresponds to the inlet of the open duct system (i.e. the trench or hole). Each sub-watershed is characterized by a number of parameters, including area, length, slope and proportion of land use respectively [18]. The area of research is calculated by using software so that the area of rain catchment in $\mathrm{m}^{2}$ is obtained.

Simulation and estimation of runoff water is essential for disaster management, planning, design and operation of water resources projects [19]. The rational method for runoff water estimates peak flow, volume, and rainfall run time distribution [20]. In the hydrological analysis of a study site, there are a number of variable factors that influence the nature of runoff. The rational method for estimating the highest runoff is expressed [21] as follows:

$$
Q=0.278 C I A
$$

where $Q=$ maximum runoff discharge $\left(\mathrm{m}^{3} / \mathrm{sec}\right), C=$ runoff coefficient representing the runoff ratio to rainfall, $I=$ mean rainfall intensity for duration which is equal to $T c(\mathrm{~mm} / \mathrm{h}), A=$ catchment area on location of the design (ha).

\subsection{Parameters of mine drainage system}

The design estimate of the flow depends on the assumption, therefore there is varying accuracy. Nevertheless, precision is required to choose an accurate friction flow formula to avoid errors. The design of mine water drainage using Manning formula [22].

$$
V=1 / n A R^{2 / 3} S^{1 / 2}
$$

where $n=$ coefficient of Manning roughness; $S=$ slope of hydraulic gradient; $R=$ hydraulic radius, $\mathrm{m} ; A=$ area, $\mathrm{m}^{2} ; V=$ velocity, $\mathrm{m}^{3} / \mathrm{s}$.

Rainwater flowing into the mines is then collected in a sump, and reused for spraying onto haul roads, conveyors and loading and unloading [23]. Excess water discharge is flowed to the surface using a drainage system. The pumping system [24] is one of the most important parts of mine water handling in coal mining research areas. Settling pond [25] is designed with certain dimensions to be able to precipitate sediment. From the sediment pond it is expected that water can flow into the river with a predetermined quality standard.

The research area is located in South Kalimantan Province, Indonesia. Based on data for 10 (ten) years, rainfall in the study area is $249.61 \mathrm{~mm} /$ year. While the number of rainy days at each year ranges from 160-257 days, with an average of 186 days/year.

\section{Results}

In order to design a mine drainage system, supporting data is needed; including a map of the mine's development plan, information on water catchment areas, rainfall data, information on rain intensity/frequency, and data on runoff discharge.

\subsection{Results of data processing}

The results of this study utilized rainfall data for the past 10 years, estimated rainfall amounts of $18.71 \mathrm{~mm} /$ day (rainfall plan), maximum daily rainfall $175 \mathrm{~mm} /$ day, and information regarding a 3 -year rain repeat period and hydrological risk of $86.83 \%$. Based on the calculation of rainfall intensity, $41.16 \mathrm{~mm} /$ hour was found. Based on observations in the field and also from studying the longterm mine plan the likelihood of flow direction of runoff was calculated.

Based on these data, the study sites were divided into 6 (six) catchment areas (see Table 1 and Figure 1). The determination of the runoff water coefficient in the mining area is influenced by several factors, including soil surface conditions. Each soil surface has a different runoff coefficient and is calculated by the rational formula stated in Table 2.

Table 3 shows the calculated result of open channel dimension. The sump discharge is adjusted with the flow of water into the pit bottom that is $65,606.37 \mathrm{~m}^{3} /$ hour. The sump design is a trapezium-shape with a volume of $128,838 \mathrm{~m}^{3}$ (see Figure 2). 


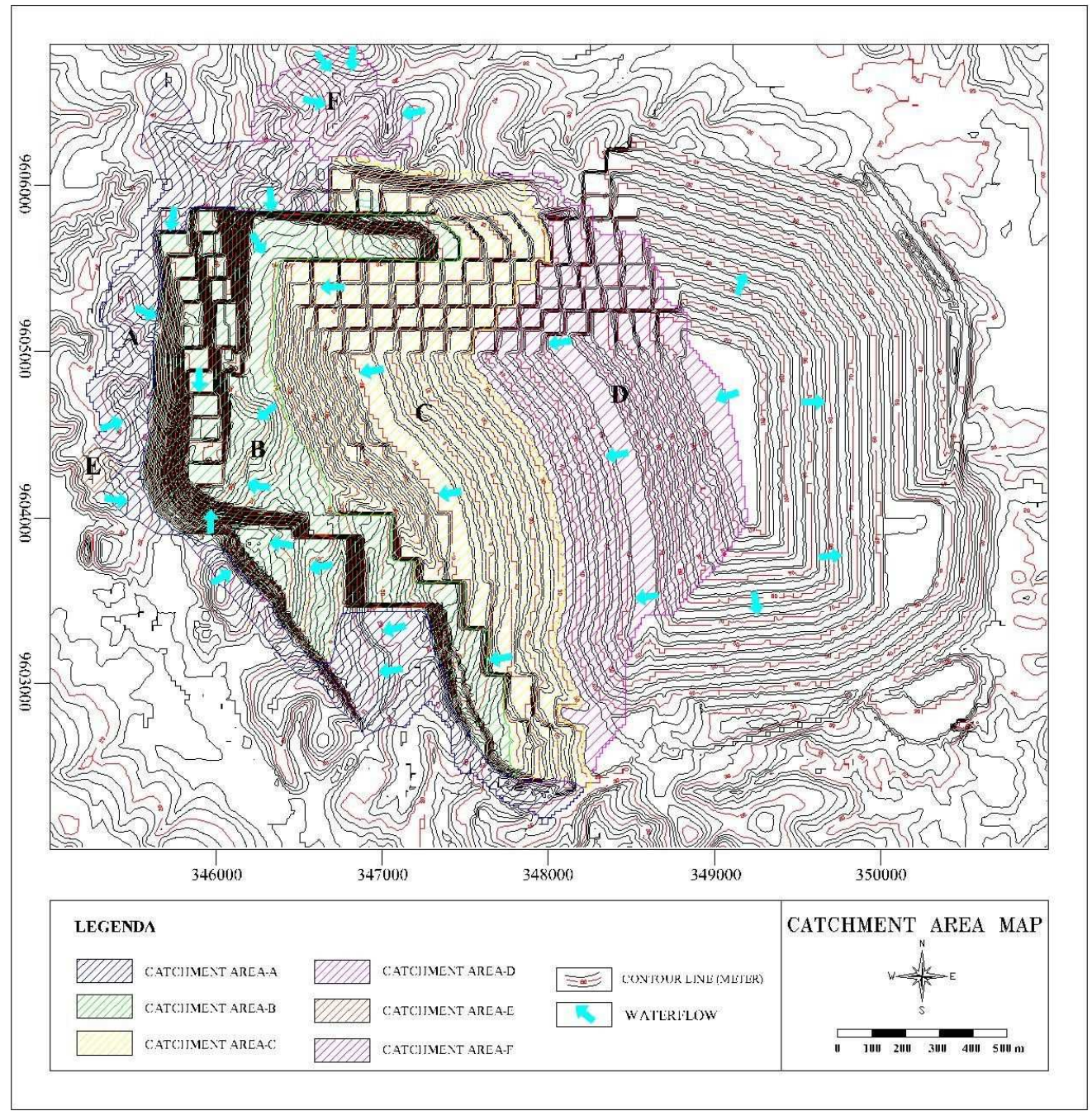

Fig. 1. Map of rainfall catchment in mine area, the colour indicates a particular catchment area and the arrow indicates the direction of the water flow.

Table 1. Catchment area within research area.

\begin{tabular}{|c|l|r|}
\hline No. & \multicolumn{1}{|c|}{ Catchment area } & Area, A (Ha) \\
\hline 1 & A (outside mine) & 63.76 \\
\hline 2 & B (pit) & 151.22 \\
\hline 3 & C (in-pit dump) & 181.49 \\
\hline 4 & D (disposal area) & 149.08 \\
\hline 5 & E (transfer sump) & 2.29 \\
\hline 6 & F (sediment pond) & 24.29 \\
\hline
\end{tabular}

Based on recommendations from geotechnical engineers, the locations of transfer sump are outside the pit area. The transfer sump distance from slope crest is $100 \mathrm{~m}$. Water volume flow rates into transfer sump is $51,823.85 \mathrm{~m}^{3}$.

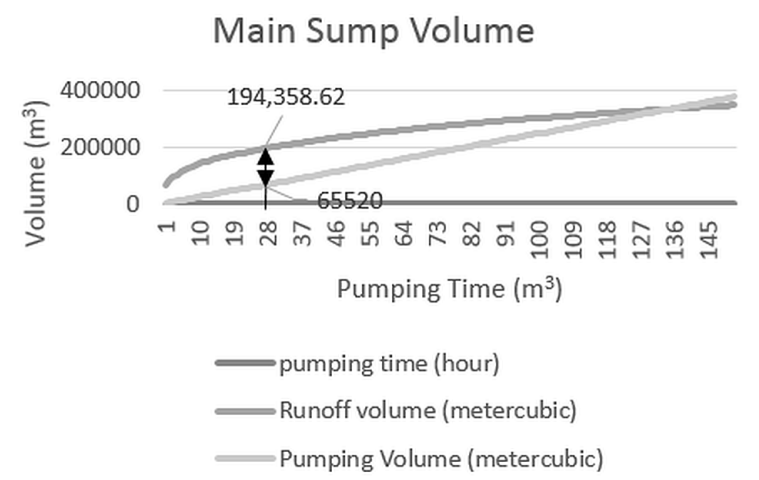

Fig. 2. Graph showing determination of the main sump volume, the optimum sump volume is the largest difference of runoff volume and water volume at 26 hours of pumping. 
Table 2. Rainfall debit calculation.

\begin{tabular}{|c|l|r|r|r|r|}
\hline No. & $\begin{array}{l}\text { Catchment } \\
\text { area }\end{array}$ & $\mathbf{A}(\mathbf{H a})$ & $\begin{array}{c}\text { I } \\
(\mathbf{m m} / \mathbf{h o u r})\end{array}$ & \multicolumn{1}{c|}{$\mathbf{C}$} & $\begin{array}{c}\mathbf{Q} \\
\left(\mathbf{m}^{\mathbf{3} / \mathbf{s}}\right)\end{array}$ \\
\hline 1 & $\begin{array}{l}\text { A (outside } \\
\text { mine) }\end{array}$ & 63.76 & 41.16 & 0.40 & 2.92 \\
\hline 2 & B (pit) & 151.22 & 41.16 & 1 & 17.30 \\
\hline 3 & $\begin{array}{l}\text { C (in-pit } \\
\text { dump) }\end{array}$ & 181.49 & 41.16 & 0.65 & 13.50 \\
\hline 4 & D (disposal) & 149.08 & 41.16 & 0.65 & 11.09 \\
\hline 5 & $\begin{array}{l}\text { E (sump } \\
\text { transfer) }\end{array}$ & 2.29 & 41.16 & 0.40 & 0.10 \\
\hline 6 & $\begin{array}{l}\text { F (sediment } \\
\text { pond) }\end{array}$ & 24.29 & 41.16 & 0.40 & 1.11 \\
\hline
\end{tabular}

Table 3. Open channel dimension.

\begin{tabular}{|l|r|c|}
\hline $\begin{array}{l}\text { Parameter of open } \\
\text { channel design }\end{array}$ & Design result & Unit \\
\hline Angle of channel & 60 & \\
\hline Channel slope $(\mathrm{m})$ & 0.58 & \\
\hline$B / d$ & 1.15 & $\mathrm{~d}^{2}$ \\
\hline$A$ & 1.73 & \\
\hline $\begin{array}{l}\text { Manning coarseness } \\
\text { coefficient }(n)\end{array}$ & 0.04 & \\
\hline Channel bottom slope & 0.02 & \\
\hline Depth of flow $(h)$ & 0.98 & $\mathrm{~m}$ \\
\hline High cage $(f)$ & 0.15 & $\mathrm{~m}$ \\
\hline Depth of channel $(d)$ & 1.13 & $\mathrm{~m}$ \\
\hline Bottom width $(b)$ & 1.30 & $\mathrm{~m}$ \\
\hline Top width $(B)$ & 2.78 & $\mathrm{~m}$ \\
\hline Channel side length $(a)$ & 1.30 & $\mathrm{~m}$ \\
\hline Wet section area & 2.21 & $\mathrm{~m}$ \\
\hline Hydraulic radius & 0.62 & $\mathrm{~m}$ \\
\hline
\end{tabular}

\subsection{Pipeline system}

The piping used in this study was HDPE (high density polyethylene) pipe with 10 in diameter and $146 \mathrm{~m}$ length from primary pump to booster pump, and 10 in diameter pipe with $382 \mathrm{~m}$ length from booster pump to outlet transfer sump. The piping from the sump transfer to the sediment pond is $1,927.82 \mathrm{~m}$. The pipeline is direct and does not follow the bench. The number of pumps in the main sump is 4 pairs, while the number of sump transfers is 4 units. The pumps are slurry pump Multiflo MF-420 E models with the booster pump being a Warman $8 / 6 \mathrm{AH}$. The maximum capacity of the pump is $630 \mathrm{~m}^{3} /$ hour, while the use of a transfer sump pump has the capacity of $635 \mathrm{~m}^{3} /$ hour.

\subsection{Settling pond}

The location of the settling pond is to the north of the mine pit as the mine digging site faces the direction to the south of the pit mine. The sediment pond at a coal mine is trapezoidal and has 4 compartments (Table 4). Based on the settling test data of the water flow from the mine site, the percentage of solids was $2.66 \%$ and the water percentage was $97.34 \%$ with the solid particle precipitation velocity of $0.0027 \mathrm{~m} / \mathrm{sec}$. Sediment clean up duration for maintenance on settling pond was 2,041.19 days (safety pond); compartment 1 was 15 days; compartment 2 was 16 days; compartment 3 was 19 days; and compartment 4 was 23 days.

\section{Discussions}

Based on the research analysis of this coal mine, the largest source of water disruption in the long-term mining plan was from runoff water. Estimated rainfall was $118.71 \mathrm{~mm} /$ day with a 3-year rain repeat period and rainfall intensity of $41.16 \mathrm{~mm} /$ hour. This amount of rain can be classified as very heavy rain. The following are respectively the discharge of runoff water in each catchment area (CA): CA-A: $2.98 \mathrm{~m}^{3} / \mathrm{sec}, \mathrm{CA}-\mathrm{B}: 17.3$ $\mathrm{m}^{3} / \mathrm{sec}$, CA-C: $13.5 \mathrm{~m}^{3} / \mathrm{sec}$, CA-D: $11.09 \mathrm{~m}^{3} / \mathrm{sec}$, CA-E: $0.1 \mathrm{~m}^{3} / \mathrm{sec}$, and CA-F: $1.11 \mathrm{~m}^{3} / \mathrm{sec}$ (see Fig. 1 and 3).

This study designed 2 (two) open channels to reduce runoff water flowing to the mine area from the rain catchment areas to the forest and disposal areas. The channel design is a $60^{\circ}$-trapezium shape. The geometry of each channel is the depth of water $(h): 0.98 \mathrm{~m}$, the depth of the channel $(d): 1.13 \mathrm{~m}$, width of channel basis $(b): 1.3 \mathrm{~m}$, surface width $(B): 2.78 \mathrm{~m}$, the outer length of the channel $(a): 1.3 \mathrm{~m}$. The design of the sump is trapezoidal with volume $128,838.62 \mathrm{~m}^{3}$. Sump transfer design is trapezoidal with volume $51,823.85 \mathrm{~m}^{3}$.

This study suggests the use of 4 pairs of pumps in the main sump and 4 pumps in the transfer sump. The total head and discharge of each pump are as follows: (1) main sump using Multiflo MF-420 E (4 units): $h t=118$ $\mathrm{m} ; \mathrm{Q}=630 \mathrm{~m}^{3} /$ hour, and $146 \mathrm{~m}$ HDPE pipes with the Warman $8 / 6 \mathrm{AH}$ booster pumps (4 units): $\mathrm{ht}=50 \mathrm{~m}, \mathrm{Q}=$ $630 \mathrm{~m}^{3} /$ hour; and HDPE pipe along $381.77 \mathrm{~m}$; (2) transfer sump using Multiflo MF-420 E (4 units): ht = $110 \mathrm{~m} ; \mathrm{Q}=635 \mathrm{~m}^{3} /$ hour, and HDPE pipe along $1,937 \mathrm{~m}$. Based on calculations in this study, the settling pond consists of 4 compartments. Percent solids in the water flow from the mine was $2.66 \%$ with settling rate of $0.0027 \mathrm{~m} / \mathrm{s}$, the particle time to settle was 30.38 minutes. The results of this study show that the percentage of theoretically suctioned particles is $83 \%$, and the maintenance time of each compartment is $15,16,19$, and 23 days respectively. 
Table 4. Settling pond dimension

\begin{tabular}{|l|c|c|c|c|c|c|c|c|}
\hline Pond compartment & $\begin{array}{c}\text { Top length } \\
(\mathbf{m})\end{array}$ & $\begin{array}{c}\text { Bottom length } \\
\mathbf{( m )}\end{array}$ & $\begin{array}{c}\text { Top width } \\
(\mathbf{m})\end{array}$ & $\begin{array}{c}\text { Bottom width } \\
\mathbf{( m )}\end{array}$ & $\begin{array}{c}\text { Depth } \\
(\mathbf{m})\end{array}$ & $\begin{array}{c}\text { Slope } \\
(\mathbf{(})\end{array}$ & $\begin{array}{c}\text { Area } \\
\left(\mathbf{m}^{\mathbf{2}}\right)\end{array}$ & $\begin{array}{c}\text { Volume } \\
\left(\mathbf{m}^{\mathbf{3}} \mathbf{)}\right.\end{array}$ \\
\hline Safety Pond & 550 & 540 & 225 & 215 & 6 & 45 & 23,950 & 719,550 \\
\hline Pond 1 & 57.75 & 47.75 & 54.75 & 44.75 & 5 & 45 & 5,000 & 12,500 \\
\hline Pond 2 & 55.17 & 45.17 & 52.17 & 42.17 & 5 & 45 & 4,500 & 11,250 \\
\hline Pond 3 & 52.44 & 42.44 & 49.44 & 39.44 & 5 & 45 & 4,000 & 10,000 \\
\hline Pond 4 & 51.01 & 41.01 & 48.01 & 38.01 & 5 & 45 & 3,750 & 9,375 \\
\hline
\end{tabular}

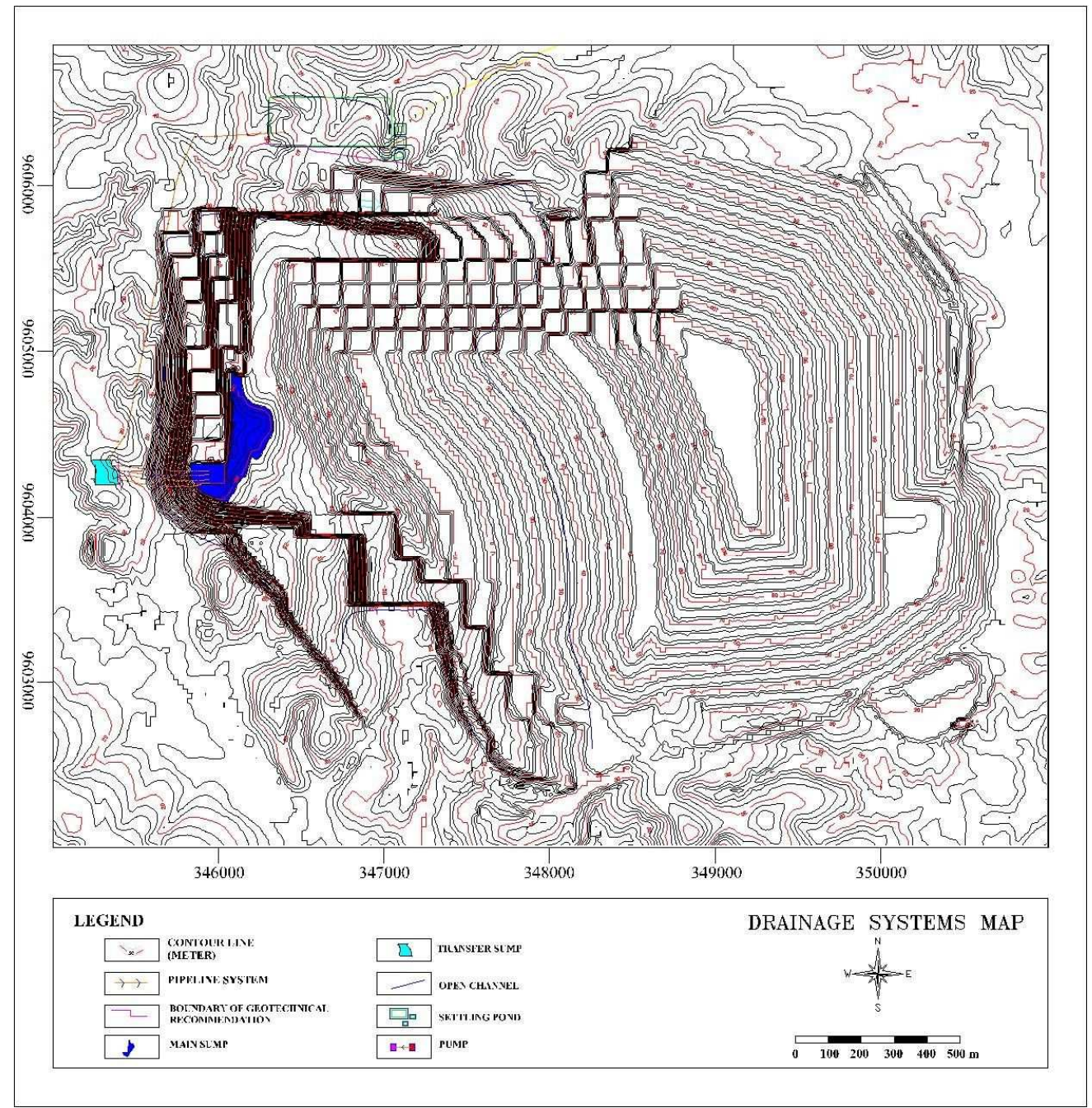

Fig. 3. Design map of coal mine drainage system based on water catchment areas, rainfall data, runoff discharge, and information on rain intensity/frequency.

\section{Conclusion and suggestion}

The study area had heavy rainfall classifications based on rainfall data for 10 years with rainfall plan of 118,71 $\mathrm{mm}$ /day, maximum daily rainfall: $175 \mathrm{~mm}$ /day with 3years rainfall period, rainfall intensity: $41,16 \mathrm{~mm} /$ hour, and hydrological risk: $86,83 \%$. The study designed two open channels to reduce runoff water flowing to the open pit coal mine from the catchment area. The design of the main and sump-transfer is trapezoidal.

This study suggests the use of four (4) pairs of pumps in the main sump and four (4) pumps in the transfer sump. The settling pond design consisted of four (4) compartments with percentage of solids in the water flow from the mine at $2.66 \%$ with a settling rate of $0.0027 \mathrm{~m} / \mathrm{s}$; the time required for the particles to settle was 30.38 minutes. The results of this study indicate that the percentage of theoretically suctioned particle is 83 $\%$, and the maintenance time of each compartment is 15 , 16,19 , and 23 days respectively. 


\section{References}

1. L. Gao, et al, Journal of Cleaner Production, Volume 162, 20 September 2017, Pages 1009-1020

2. P. Hobbs, International Journal of Water Resources Development, Volume 24, Issue 3 (2008)

3. A.R. Álvarez, et al, Engineering Geology, Volume 232, Pages 114-122 (2018)

4. A.K. Soni, et al, Mine Water, International Journal of Mining, Reclamation, and Environment, Volume 30 -Issue 2 (2016)

5. E. Bozau, et al, Chemie der Erde - Geochemistry, Volume 77, Issue 4, Pages 614-624 (2017)

6. W.S. Bargawa, paper presented in International Conference on Science and Technology 3 - UGM (2017)

7. G. Lee, et al, Journal of Cleaner Production, Volume 186, Pages 282-292 (2018)

8. A.K. Soni, Journal of Mines, Metals \&Fuels, 64 (9), Page 406-413, ISSN 0022-2755 (2016).

9. G. Vižintin, et al, Science of The Total Environment, Volumes 619-620, Pages 1214-1225 (2018)

10. S.E. Mhlongo and F.A. Dacosta, International Journal of Mining, Reclamation and Environment, Volume 30, Issue 4 (2016)

11. I. Nancucheo, et al, Biomed Res Int. 2017: 7256582 (2017)

12. G. Kaur, et al, Journal of Water Process Engineering, Volume 22, Pages 46-58 (2018)

13. Y. Zhang, et al, Journal of Hydrology, Volume 525, Pages 72-86 (2015)

14. F. Serinaldi, et al, Journal of Hydrology, Volume 512, Pages 285-302 (2014)

15. R. Nigam, et al, International Journal of Hydrology Science and Technology, Vol. 4, No.2, pp. 81-109 (2014)

16. M. Meddi, S. Toumi, Journal of Mountain Science 12 (6). DOI: 10.1007/S1 1629-014-3084-3 (2015)

17. M. S. Kang, et al, Journal of Hydro-environment Research, Volume 7, Issue 3, Pages 209-218 (2013)

18. S. Zhang, et al, Science of The Total Environment, Volume 574, Pages 34-45 (2017)

19. L. Zhao, et al, Soil and Tillage Research, Volume 179, Pages 47-53 (2018)

20. S.O. Rodriguez, et al, Journal of Hydrology, Volume 531, Part 2, Pages 389-407 (2015)

21. R.D. Nicolas, et al, International Journal of Hydrology Science and Technology, Vol. 6, No.1 (2016)

22. R. Moussa, and C. Bocquillon, Journal of Hydrology, Volume 186, Issues 1-4, Pages 1-30 (1996)

23. K. Yamaguchi, et al, Journal of Environmental Sciences, Volume 36, Pages 130-143 (2015)

24. D. Shang, International Journal of Rotating Machinery, Volume 2017, 8 pp (2017)
25. Li Gu, et al, Canadian Water Resources Journal, Volume 42, Issue 1 (2017) 